\title{
Board game for the engineering students to promote interest in city infrastructure courses
}

Kristina Kokina $^{1}$, Linda Mezule ${ }^{1}$, Anatolijs Borodinees ${ }^{2}$

${ }^{1}$ Department of Water Engineering and Technology, Riga Technical University, Latvia, ${ }^{2}$ Department of Heat, Gas and Technology, Riga Technical University, Latvia.

\begin{abstract}
Learning is a complex process that includes self-motivation, self-control and self-discipline. The efficiency of learning depends on the motivation of students and overall atmosphere in the classroom. At the same time, promotion of interest to communicate out of the classroom is of the same importance. Furthermore, if students find an interest in a specific professional field during the out-of-classroom activities, the study process in engineering sciences becomes easier and more enjoyable.

To promote the interest in engineering studies at Riga Technical University study programme Heat, Gas and Water Technology, workshops at the infrastructure units of the related industry representatives, summer workshops in the sports, seminar and recreation centre, as well as basketball and table tennis competition between teachers and students are organized on a regular basis. Through the thematic games, teachers find the motivation to upgrade the quality of the study process and students gain more information on the topic and ability to achieve higher results. The proposed board game for the out-ofclassroom activities is a successful method to facilitate the communication between lecturers and students in practice. At the same time, the game contains control questions that allow to stimulate and promote the knowledge level of the students.
\end{abstract}

Keywords: Gamification; course organization; time management; communication; out-of-classroom; board game. 


\section{Introduction}

"Active learning" process where both a teacher and a student are interactively involved in the study process, has received considerable attention over the years. Teachers are constantly looking for new methods to increase the knowledge of students and to grow new professionals. Sometimes they do serious preparatory work to adapt new study materials or use different approaches for teaching. Through this type of learning, self-motivation, selfcontrol, and self-discipline is facilitated for the students: Aksit et al. (2016). Nevertheless, the communication between the teacher and the student is the key factor in effective learning.

Usually, the teacher is responsible for the motivation of students to learn new things, adapt new study course concepts and different learning styles, and manage the classroom in general: Sword (2020). Good communication skills are characterized by the ability to communicate with students, parents, and colleagues: Silver (2018), Sword (2020). However, sometimes pure communication in the classroom between the teacher and students is not sufficient. Out-of-classroom gamification methods allow to create an interest not only from the students who gain more practical understanding about the requirements of the field but also from the representatives of the industry that are interested in communication with the new specialists and want to develop strong contacts with the university: Tihomirova (2019).

The Importance of Promoting Interest has equally significant position: Harackiewicz et al. (2016). When someone has an interest in a professional topic, the learning process becomes easier and more enjoyable, the motivation to learn new things increases; Cumberland (2014), Cuhna et al. (2020). The promotion of interest can be produced through various communication techniques or models such as learning: (i) particular situations that trigger interest; (ii) features of the environment (e.g., surprise) that catch the person's attention; (iii) repeated experiences of triggered and maintained situational interest; (iv) self-sustaining, well-developed, individual interest (e.g., the student visits art museums): Harackiewicz et al. (2016). Thus, the key in student academic success lays in positive, confident, engaging emotions and interest in the specific study field: Harackiewicz et al. (2016), Sword (2020).

Institute of Heat, Gas and Water technologies of Riga Technical University provides all level higher education (Bachelor professional, Master academic and Doctoral studies) and performs research in the field of heating, ventilation, air-conditioning, water and wastewater treatment and distribution systems. The academic staff of the Institute applies different teaching methods in routine work, organises workshops both in the university and in the outof-classroom environment. These workshops usually take place at the territories of the cooperation partners or university outdoor areas. Furthermore, regular basketball or table tennis competition is organized between teachers and students to promote the interest and communication willingness from students. Within this paper we aim to demonstrate the primary rules of a board game that has been developed for out-of-classroom activities of 
students from study programmes related to heat, gas and water technologies to promote communication and interest in the specific engineering field.

\section{Basic Rules}

Quiz games like Linkee, Colorbrain or Shot in the Dark are among the most popular board games: Graham (2020). Adaptation of these or similar board games for training purposes has been already reported. Their modifications by using specific questions of some professional field allow to stimulate knowledge level of the students in the particular field. Also, there are several examples by using modified Monopoly game to increase the level of motivation, understanding, critical thinking and decision-making skills in students: Shanklin \& Ehlen (2007), Oliveira et al. (2015), Dirgantara et al. (2018). At the same time, modifications suitable for heat, gas and water engineers have not been reported.

A table game described in this manuscript is a combination of "Monopoly" and typical quiz games. It was developed to promote the interest in engineering students through the out-ofclassroom activities with or without the lecturers. The game contains quiz questions from the field of infrastructure development and urban planning that allow to repeat study topics, increase the speed of thinking and, as result, the knowledge of the field. Playing the game is also a successful method to facilitate the communication between the lecturers and students.

\subsection{Description of the rules}

Basic rules of the game are similar to "Monopoly" (www.hasbro.com). However, there are multiple modifications when compared with the original game version (Table 1).

Table 1. New terms and replacements introduced in the table game for heat, gas and water engineers.

\begin{tabular}{llcl}
\hline & Original title & Number of players & Replacement \\
\hline 1 & Bank & 1 & Head of Urban Planning Department \\
2 & Jail & 1 & Engineer Certification Centre \\
3 & Player & $2+$ & Engineer \\
4 & Free parking & & Vacation \\
5 & Chance & Energy audit \\
6 & Street & Elements of city infrastructure \\
\hline
\end{tabular}

To play, a special board (Figure 1), quiz cards, play money, player tokens, colour chips and two six-sided dice are needed. The game can be played by $2+$ students. According to the 
classic rules, the player that roles the highest total on both dice goes first. Game play proceeds clockwise from that player. Starting capital of each player is 1500 money units (MU).

Head of urban planning department $(n=1)$ is responsible for splitting the funding between the players and control of money, all property and infrastructure until it is introduced in the game.

Head of certification commission $(n=1)$ is responsible for the certification of an engineers (engineer project quality).

Each time the engineers $(n=2+)$ pass 'Lets' Go', they collect a Salary of $200 \mathrm{MU}$ from the Urban Planning Department.

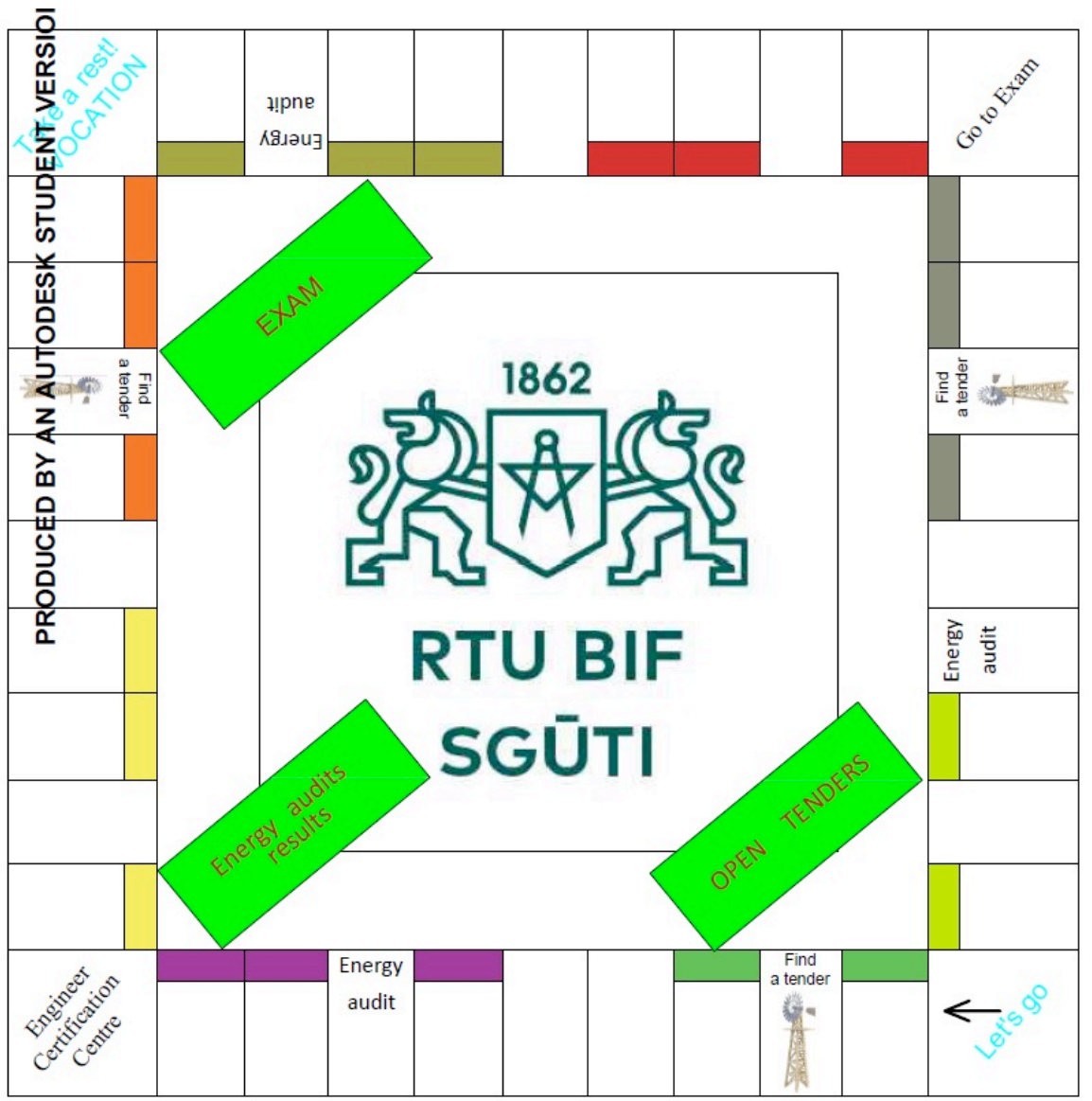

Figure 1. Schematic representation of the table board for the game.

Each colour on the board represents different types of city infrastructures (Table 2) that are further divided into three or two parts. If it is not already occupied by other engineers, each player can submit an infrastructure development project to the Urban Planning Department for 
any property that he/she lands on. The project (50 MU) can be submitted and realized only for one type of infrastructure system per round $\left(1^{\text {st }}, 2^{\text {nd }}\right.$ and $3^{\text {rd }}$ upgrades $)$. The type of the realised project is indicated by special coloured coded chip from Urban Planning Department (Figure 1). With each implemented project, the utility bills to other players increase by $10 \%$. If engineers do not submit the project for a property, the Urban Planning Department can announce a public auction starting from the lowest price.

Infrastructure projects can be realized by different engineers. Players can sell and buy projects for any property that they land on or outsource (50 MU or $10 \%$ of your total object price). In this case the incomes from the object are divided between the project engineers.

Players can get extra funding from Urban Planning Department by implementing energy audits. When a player lands on "Energy audit", they take a card from "Energy audit" quiz. If the Energy audit is passed, the engineer gets money from Urban Planning Department (50MU), if it is failed the engineer should return money (50MU) to Urban Planning Department. Also, if a player can pass three Energy audits in a row for one of its properties, he/she can double the income from Urban Planning Department.

Transfer to "Engineer Certification Centre" is possible through landing on a field marked 'Go to Exam', draw a card marked 'Go to Exam' or roll doubles three times in a row.

There are only 2 ways to pass the "Engineer Certification Centre":

1) Take a card form the Certification committee in heat, gas or water field (choose only one field). The card contains one question and 3 answers (one is correct). Answer the question. If the answer is correct, the player continues the game and receives a certificate which increases the rent price by $10 \%$ of all players property until the player finishes the round.

2) After the third failed answer, the engineer must pay the $50 \mathrm{MU}$ fine and leave the "Engineer Certification Centre" without a certificate. Then the used cards are returned to the bottom of the pile the action is completed.

The engineer can choose to sell a part or full set of their property to Urban Planning Department or to end the game when all fields are equipped with all level of infrastructure upgrades.

Field "Find a tender" provides income or loss of money due to participation in construction works. The player chooses a card and according to it, the player gets money from the owner of next closest field with upgraded infrastructure. Loss of money is indicated in a card which indicates the amount to be returned to Urban Planning Department.

The winner of the game is the one who remains the last in the game or holds most of the finances (estimated both in cash and owned property). 
Table 2. Sample of principial scheme of game sequence.

\begin{tabular}{|c|c|c|c|c|}
\hline \multirow[t]{2}{*}{ Infrastructure } & \multirow{2}{*}{$\begin{array}{l}\text { Type of } \\
\text { subsystems }\end{array}$} & \multicolumn{3}{|l|}{ Upgrades } \\
\hline & & $1^{\text {st }}$ level & $2^{\text {nd }}$ & $3^{\text {rd }}$ \\
\hline \multirow[t]{3}{*}{ District heating } & $\begin{array}{l}\text { Combined } \\
\text { heat and } \\
\text { power }\end{array}$ & $\begin{array}{l}\text { new filter, better } \\
\text { boilers }\end{array}$ & $\begin{array}{l}\text { Change from fossil fuels } \\
\text { to renewable energy }\end{array}$ & $\begin{array}{l}\text { Installation of } \\
\text { solar renewable } \\
\text { energy and } \\
\text { thermal storage }\end{array}$ \\
\hline & $\begin{array}{l}\text { Heat } \\
\text { distribution } \\
\text { metwork }\end{array}$ & $\begin{array}{l}\text { Installation of new } \\
\text { or replacement of } \\
\text { old pipes }\end{array}$ & $\begin{array}{l}\text { Operation temperature } \\
\text { reduction transition from } \\
\text { 3rd generation to } 4 \text { th } \\
\text { generation }\end{array}$ & $\begin{array}{l}\text { transition from } \\
\text { 4th generation to } \\
5 \text { th generation }\end{array}$ \\
\hline & $\begin{array}{l}\text { Heat } \\
\text { substations }\end{array}$ & $\begin{array}{l}\text { Better regulation } \\
\text { based on outdoor } \\
\text { sensors }\end{array}$ & $\begin{array}{l}\text { Advanced control with } \\
\text { temperature regulation } \\
\text { schedule }\end{array}$ & $\begin{array}{l}\text { Bidirectional } \\
\text { heat substation }\end{array}$ \\
\hline \multirow[t]{3}{*}{ Gas } & $\begin{array}{l}\text { Distribution } \\
\text { network }\end{array}$ & $\begin{array}{l}\text { Replacement of } \\
\text { pipelines }\end{array}$ & Network extension & $\begin{array}{l}\text { SNG vehicle } \\
\text { network }\end{array}$ \\
\hline & $\begin{array}{l}\text { Compressor } \\
\text { stations }\end{array}$ & $\begin{array}{l}\text { Upgrade to new } \\
\text { equipment }\end{array}$ & $\begin{array}{l}\text { ICT for remote } \\
\text { monitoring and } \\
\text { maintenance }\end{array}$ & $\begin{array}{l}\text { Integration of } \\
\text { biogas }\end{array}$ \\
\hline & $\begin{array}{l}\text { Emergency } \\
\text { services }\end{array}$ & $\begin{array}{l}\text { New transport and } \\
\text { equipment }\end{array}$ & $\begin{array}{l}\text { Integrated solution with } \\
\text { state fire and } \\
\text { rescue service of Latvia }\end{array}$ & $\begin{array}{l}\text { New app for } \\
\text { communication }\end{array}$ \\
\hline \multirow[t]{3}{*}{ Wastewater } & $\begin{array}{l}\text { Wastewater } \\
\text { treatment } \\
\text { plant }\end{array}$ & $\begin{array}{l}\text { Project and } \\
\text { building }\end{array}$ & System monitoring & $\begin{array}{l}\text { Optimization of } \\
\text { process }\end{array}$ \\
\hline & $\begin{array}{l}\text { Sewage } \\
\text { system }\end{array}$ & $\begin{array}{l}\text { Installation of new } \\
\text { pipes }\end{array}$ & Building of pump station & $\begin{array}{l}\text { Installation of } \\
\text { online } \\
\text { monitoring } \\
\text { system }\end{array}$ \\
\hline & $\begin{array}{l}\text { Individual } \\
\text { wastewater } \\
\text { treatment } \\
\text { system }\end{array}$ & $\begin{array}{l}\text { Project and } \\
\text { construction }\end{array}$ & Quality monitoring & $\begin{array}{l}\text { Additional stages } \\
\text { for process } \\
\text { optimization }\end{array}$ \\
\hline
\end{tabular}

A number of examples for use of gamification in different levels of education can be found. Gamification in teaching process is an excellent approach to make the atmosphere in the classroom more positive and open. It is often used to increase students' motivation and engagement in educational environments and stimulate their learning interest at all levels of studies: Dichev \& Dicheva (2017), Wang \& Wang (2018). The gamification allows to receive additional attention of learners and motivate them for self-study also out-of-classroom. Board games allow to put the focus on student interactions, encourage healthy competition between classmates, stimulate work together to solve the game, reduces stress, encourage creative and strategic thinking and provide a break from traditional lesson structure. At the same time, it 
should be noted, that the board games used for studies are not developed to replace a whole study course. They are only an interactive part of studies or teaching process to promote the interest in the specific study field.

\section{Conclusions}

To increase the knowledge level and communication skills of students in heat, gas and water engineering field, a table game has been designed for out-of-classroom activities. The game combines traditional board game style with technical terms and details from the specific engineering field. Various infrastructure units have been selected and their modifications introduced in the game. The principles of the game are simple, and it can be also used by non-professionals. Furthermore, parts of the game, especially quiz and "Energy audit" cards can be replaced or modified according to the knowledge level of the players.

Use of gamification during the study process and out-of-classroom activities allows us to increase the interest in students, facilitate their self-learning, and stimulate their effort to achieve the result. Modified and specialized board games can become equally important in the study as role plays and practical discussions.

Our board game has been developed as additional tool for out-of-classroom activities of students without formal assessment and examinations. It aims to promote communication and interest in the specific engineering field. Alternatively, it can be also used in competitions not only with course members, but also with teachers participating in the game.

\section{References}

Aksit, F., Niemi, H.\& Nevgi, A. (2016). Why is active learning so difficult to implement: The Turkish case. Australian Journal of Teacher Education, 41(4), 94-109. doi: 10.14221/ajte.2016v41n4.6.

Cumberland, S. (2014, March 21) The Importance of Interest in Learning. Message posted to https://www.schooliseasy.com

Cunha, R. S., Ribeiro, L. M., Sequeira, C., B., Rita de Almeida, C., L., \& Dias, T. S. (2020). What makes learning easier and more difficult? The perspective of teenagers. Psicologia em Estudo, 25, e46414. doi: 10.4025/psicolestud.v25i0.46414.

Dichev, C. \& Dicheva, D. (2017). Gamifying education: what is known, what is believed and what remains uncertain: a critical review. International Journal of Educational Technology in Higher Education, 14, 9. https://doi.org/10.1186/s41239-017-0042-5.

Dirgantara, M. R. D., Susilowati, S. M. E., \& Marwoto, P. (2018). The Use of Monopoly Media to Improve Primary Student's Critical Thinking Skills in Science Learning. Journal of Primary Education, 8(3), 262-269. Retrieved from https://journal.unnes.ac.id/sju/index.php/jpe/article/view/26652 
Graham, L. (2020, June 17) 10 best trivia games that are better than Trivial Pursuit. Message posted to https://www.dicebreaker.com

Harackiewicz, J., Smith, J. \& Priniski, S. (2016). Interest Matters: The Importance of Promoting Interest in Education. Policy Insights from the Behavioral and Brain Sciences, 3 (2). doi: 10.1177/2372732216655542.

Oliveira, A. P. A., Werneck, V.M.B., Leite, J. C. S. P., \& Cysneiros, L.M. (2015). The Monopoly Game to Teach $\mathrm{ERi}^{*} \mathrm{c}$ - Intentional Requirements Engineering. CEUR Workshop Proceedings. 1370, 49-54. Retrieved from http://ceur-ws.org

Shanklin, S. B. \& Ehlen, C.R. (2007) Using the Monopoly Board Game as An In-Class Economic Simulation in The Introductory Financial Accounting Course. Journal of College Teaching \& Learning, 4 (11), 65-72. doi: https://doi.org/10.19030/tlc.v4i11.1525.

Silver, F. (2018, July 01) Why Is It Important for Teachers to Have Good Communication Skills? Message posted to https://work.chron.com

Sword, R. (2020, November 16) Effective Communication in the Classroom: Skills for Teachers. Message posted to https://www.highspeedtraining.co.uk

Tihomirova, K., \& Mezule, L. (2019). Management of wastewater trough theatre. International Conference on Higher Education Advances, 1137-1144. doi: 10.4995/HEAD19.2019.9162.

Wang, M. \& Wang, L. (2018) Teaching Games for Understanding Intervention to Promote Physical Activity among Secondary School Students. BioMed Research International, article ID 3737595. doi: 10.1155/2018/3737595. 